УДК 691.175.743

\title{
ВЛИЯНИЕ МОДИФИКАТОРОВ \\ НА ТЕХНОЛОГИЧЕСКИЕ ПАРАМЕТРЫ ПРОИЗВОДСТВА ПОЛИВИНИЛХЛОРИДНЫХ КОМПОЗИЦИЙ
}

Хузиахметова Карина Рустамовна
аспирант
Крайсман Кристина Денисовна студент Научный руководитель: Низамов Рашит Курбангалиевич д.т.н., профессор, ректор ФГБОУ ВО «Казанский государственный архитектурно-строительный университет»

Аннотация: Сложность переработки поливинилхлоридных композиций приводит к необходимости его модификации акриловыми технологическими добавками. В исследовании представлено сравнение влияния на экструзионную переработку ПВХ одного из самых востребованных зарубежных (FM-50) и российских (АБС-20П) модификаторов.

Ключевые слова: поливинилхлорид, акрилонитрил-бутадиен-стирол, модификатор, экструзия, расплав.

\section{EFFECT OF MODIFIERS ON THE TECHNOLOGICAL PARAMETERS OF POLYVINYL CHLORIDE COMPOSITIONS PRODUCTION}

\section{Khuziakhmetova Karina Rustamovna Krasman Kristina Denisovna}

\footnotetext{
Abstract: the complexity of processing polyvinyl chloride compositions leads to the necessity of its modification by acrylic technological additives. The study presents a comparison of the effect of one of the most demanded foreign (FM-50) and Russian (ABS-20P) modifiers on PVC extrusion processing.

Keywords: polyvinyl chloride, acrylonitrile butadiene styrene, modifier, extrusion, melt.
} 
Модификация полимерных материалов дает возможность использовать их практические во всех отраслях промышленности [1, с. 30]. Введение в состав технологических добавок, стабилизаторов, наполнителей, красителей, пигментов и т.д. позволяет обеспечить рост требований к эксплуатационным и технологическим свойствам таких материалов [2, с. 56].

Одним из крупнотоннажных строительных полимерных материалов является поливинилхлорид (ПВХ) [3, с. 6], внутренняя структура и строение которого позволяет перерабатывать его в различные профильно-погонажные изделия (листы, оконные профили, трубы, сайдинг и т.п.) [4, с. 28]. Частой проблемой использования ПВХ является склонность к термической деструкции (в результате воздействия высоких температур) или повышенная вязкость расплава, которые можно нивелировать модификацией акриловыми технологическими добавками [5, с. 35].

Распространенным зарубежным модификатором является сополимер акрилонитрил-бутадиен-стирола (АБС), который позволяет повысить совместимость с ПВХ благодаря своей полярности [6, с. 645]. На сегодняшний день одним из лидирующих российских предприятий по изготовлению АБС является АО «Пластик» (г. Узловая) [7, с. 21]. Поэтому особый интерес заключается в модификации ПВХ российским АБС.

В данном исследовании приведено сравнение воздействия двух модификаторов на ПВХ-композиции - FM-50 и АБС-20П, состав которых представлен в таблице 1.

Таблица 1

\section{Состав экспериментальных композиций}

\begin{tabular}{|c|c|c|}
\hline Компонент & \multicolumn{2}{|c|}{ Концентрация, мас.ч. } \\
\hline ПВХ & \multicolumn{2}{|c|}{5} \\
\hline Двухосновный стеарат свинца & \multicolumn{2}{|c|}{3} \\
\hline Стеарат кальция & 7 & - \\
\hline FМ-50 & - & 7 \\
\hline АБС-20П & \multicolumn{2}{|c|}{} \\
\hline
\end{tabular}

В состав порошкообразных композиций входит ПВХ марки С-6359-М (ГОСТ 14332-78), комплексный стабилизатор в виде двухосновного стеарата свинца, а также стабилизатор-смазка - стеарат кальция (ТУ 6-09-4104-87). Композиция 1 модифицирована FM-50, выпускаемым в Бельгии. Композиция 2 
была модифицирована АБС-20П, выпускаемым в России Узловским АО «Пластик». АБС-20П имеет температуру размягчения порядка $100^{\circ} \mathrm{C}$ и показатели текучести расплава при $220^{\circ} \mathrm{C}$ и 10 кгс не менее 5-12 г/10 мин.

Предварительное перемешивание порошкообразных компонентов осуществлялось на лабораторном смесителе ЛДУ-3 МПР с пропеллерной насадкой в течение 4 мин при 700 об/мин.

На лабораторном экструдере LabTechScientific LTE 16-40 были получены плоские профили размером $2 \times 22$ мм или более (в зависимости от коэффициента разбухания расплава) и длиной 20-25 см. Температурный режим регулировался по десяти зонам цилиндра (таблица 2).

Таблица 2

Температурный режим экструдирования

\begin{tabular}{|c|c|c|c|c|c|c|c|c|c|c|}
\hline Зоны цилиндра & 1 & 2 & 3 & 4 & 5 & 6 & 7 & 8 & 9 & 10 \\
\hline Температура, $^{\circ} \mathbf{C}$ & 190 & 193 & 195 & 195 & 197 & 197 & 197 & 200 & 200 & 200 \\
\hline
\end{tabular}

Важным фактором при модификации является изменение режимов экструзии, главными из которых являются давление расплава в фильере и степень загруженности двигателя от максимальной мощности. Данные показатели не должны достигать «критических величин», которые могут привести к блокировке или возможной поломке экструдера. Поэтому были проанализированы основные параметры экструзионной переработки композиций (таблица 3).

Таблица 3

Параметры экструзионной переработки

\begin{tabular}{|c|c|c|c|c|}
\hline Модификатор & $\begin{array}{c}\text { Скорость } \\
\text { шнеков, об/мин }\end{array}$ & $\begin{array}{c}\text { Давление в } \\
\text { фильере, бар }\end{array}$ & $\begin{array}{c}\text { Загрузка } \\
\text { двигателя, \% }\end{array}$ & Разбухание \\
\hline FМ-50 & 16 & 14 & 45 & 1,5 \\
\hline АБС-20П & 16 & 12 & 33 & 1,3 \\
\hline
\end{tabular}

При одинаковых скоростях вращения шнеков наблюдается изменение давления расплава в фильере и, как следствие, загрузки двигателя, а именно увеличение данных показателей при введении в ПВХ-композиции модификатора FM-50. Это может быть связано с тем, что в зоне фильеры происходит накопление расплава, повышающего вязкость. Кроме того, в 239 
процессе формования изделий при использовании обоих модификаторов наблюдается эффект разбухания экструдата, связанный с повышением скорости сдвига расплава при его накоплении в зоне фильеры [8, с. 362].

Вязкость расплава оказывает значительное влияние на производительность экструзионной переработки. Обратной величиной вязкости является предел текучести расплава. Испытание проводилось на пластометре Франка (ГОСТ 11645-73) и рассчитывалось по массе шести образцов, вышедших из капилляра, при нагреве до $185^{\circ} \mathrm{C}$ и нагружении 21,6 кг.

Термостабильность (ГОСТ 14041-91) определялась на пленочных образцах размером $2 \times 2$ мм весом 2-4 г, и характеризовалась временем индукционного периода от начала погружения пробирки в термическую печь до изменения цвета индикатора в процессе выделения $\mathrm{HCl}$ во время дегидрохлорирования ПВХ при $180{ }^{\circ} \mathrm{C}$.

Изменение линейных размеров (ГОСТ 30673-2013) определялось по «рискам» на двух экструдированных образцах длиной 220土0,2 мм, вырезанных в продольном направлении и помещенных в сушильный шкаф 2B-151, нагретый до температуры $100 \pm 2^{\circ} \mathrm{C}$ в течение 60 мин.

Технологические параметры представлены в таблице 4.

Таблица 4

Технологические параметры ПВХ-композитов

\begin{tabular}{|c|c|c|c|}
\hline Модификатор & $\begin{array}{c}\text { Предел текучести } \\
\text { расплава, г/10 мин }\end{array}$ & $\begin{array}{c}\text { Термостабильность, } \\
\text { мин }\end{array}$ & $\begin{array}{c}\text { Изменение } \\
\text { линейных размеров, } \\
\text { \% }\end{array}$ \\
\hline FМ-50 & 1,852 & 95 & 0,51 \\
\hline АБС-20П & 2,362 & 91 & 0,25 \\
\hline
\end{tabular}

Модификатор АБС-20П позволяет повысить предел текучести расплава на $28 \%$, что объясняется более выраженной совместимостью компонентов ПВХ и АБС. Влияние обоих модификаторов на термостабильность и изменение линейных размеров находится в одном диапазоне, что говорит о повышенной стойкости к температурным воздействиям.

Таким образом, представленные результаты говорят о том, что повышенная совместимость ПВХ с модификатором АБС-20П позволяет снизить вязкость и давление расплава в фильере, повышая производительность экструдера. А необходимая термостабильность и минимальное изменение 
линейных размеров позволяет рекомендовать АБС-20П как эффективный модификатор для ПВХ-композиций.

\section{Список литературы}

1. Абдрахманова, Л.А. Полимерные строительные материалы на основе поливинилхлорида / Л.А. Абдрахманова, Р.К. Низамов // Полимеры в строительстве: научный интернет-журнал. - 2014. - № 1(1). - С. 29-48.

2. Лавров, Н.А. Полимерные смеси на основе поливинилхлорида (обзор) / Н.А. Лавров, Е.В. Белухичев // Пластические массы. - 2020. - № 3-4. - С. 55 59. - DOI 10.35164/0554-2901-2020-3-4-55-59.

3. Огрель Л.Д. Российский рынок полимеров и изделий из них / Л.Д. Огрель // Полимерные материалы. - 2020. - №3. - С.4-12.

4. Уилки Ч., Саммерс Дж., Даниелс Ч. Поливинилхлорид / Пер. с англ. под ред. Г.Е. Заикова. СПб.: Профессия, 2007. 728 с.

5. Модификаторы для жестких поливинилхлоридных композиций строительного назначения / Л.А. Абдрахманова, К.Р. Хузиахметова, Р.К. Низамов, В.Г. Хозин // Строительные материалы. - 2020. - № 12. - С. $34-$ 39. - DOI 10.31659/0585-430X-2020-787-12-34-39.

6. Mehdipour M. R., Talebi S., Razavi Aghjeh M.K. Effect of unplasticized poly vinyl chloride (UPVC) molecular weight and graft-acrylonitrilebutadienestyrene ( $\mathrm{g}$-ABS) content on compatibility and izod impact strength of UPVC/g-ABS blends // Journal of Macromolecular Science: Physics. - 2017. - № 9(56). - P. 644-654. DOI: 10.1080/00222348.2017.1360684.

7. Барсамян Г.Б. Модификаторы для жесткого ПВХ // Пластикс. - 2017. -№ 3(165). - С. 21-23.

8. Раувендааль К. Экструзия полимеров / пер. с англ. яз. 4-го изд. под ред. А.Я. Малкина. СПб.: Профессия, 2008. 768 с.

(C) К.Р. Хузиахметова, К.Д. Крайсман, 2021 